\title{
GRZECH JAKO CZYNNIK DEZINTEGRUJĄCY ŻYCIE SPOŁECZNE TEMATEM KAZNODZIEJSKICH ROZWAŻAŃ ANTONIEGO WEGGRZYNOWICZA (1658-1721)
}

\section{Wstęp}

Pojęcie grzechu jest przywoływane najczęściej w kontekstach antropologicznym, socjologicznym i religijnym. W zależności od założeń światopoglądowych grzech jest postawą, czynem, aktem niesprawiedliwym, odnoszącym się do zła, który przekracza i narusza prawa naturalne, boskie, kosmiczne lub społeczne. Jest owocem ludzkiej wolności niejednokrotnie prowadzącym do alienacji jednostki i niespełnienia jej. Dyskredytuje godność człowieka. Grzech, odnosząc się do sytuacji egzystencjalnej (bytowej), oznacza moralne wypalenie i zawód, także niezdarność. Dotyczy egocentryzmu człowieka i odzwierciedla się w trzech znaczeniach: splamienie czystości, grzech jako złamanie (zerwanie) swobody danej człowiekowi przez Boga i gotowość do bycia karanym.

Wymyka się on jednak absolutnej definicji. Łatwiej scharakteryzować jego konsekwencje: zło i śmierć. Odczuwanie grzechu w kulturze europejskiej wynikało z dziedzictwa antycznej kultury śródziemnomorskiej i religijnej tradycji judeochrześcijańskiej. Grzech w rozważaniach biblijnych oznacza zło etyczne. W Starym Testamencie znaczy tyle, co przekroczenie prawa. Opisywany jest jako świadome i dobrowolne wykroczenie przeciw prawu bożemu i obraza Boga, która prowadzi do zerwania mistycznej więzi ze Stwórcą i uniemożliwia osiągnięcie Królestwa Niebieskiego. W Nowym Testamencie grzech oznacza niewiarę, odrzucenie Chrystusa i jego orędzia miłości. Jest świadomym przewinieniem wobec woli Bożej i dotyczy czynu. $\mathrm{W}$ tradycji chrześcijańskiej człowiek dziedziczy grzech. Uwaga zatem

„Nasza Przeszłość” t. 132: 2019, s. 113-125. 
zostaje zwrócona na możliwość ochrony przed grzechem i sprawy związane z zadośćuczynieniem, pokutą i obmyciem z niego ${ }^{1}$.

Grzech dzięki swojej powszechności jest integralnym rysem ludzkiego doświadczenia, tak indywidualnego jak i społecznego. O grzechu na przestrzeni dziejów myśli teologicznej pisało wielu. Miano „mistrza nauki o grzechu” przypadło św. Tomaszowi z Akwinu, który grzechowi poświecił sporo uwagi w swej Summie teologicznej ${ }^{2}$.

Ojcowie i doktorowie Kościoła udowadniali, że grzech jest obrazą Boga, zerwaniem z nim więzi, rezygnacją z jego opieki i tym samy utratą zbawienia, czyli wiecznym potępieniem.

Takie myślenie zostało gruntowane przez scholastyczny model duchowości, który oddziaływał długo i zauważalny był jeszcze w XVIII wieku, także w kontekście reform potrydenckich ${ }^{3}$. Moraliści doby saskiej uważali, że grzech jest przestąpieniem prawa Bożego, tak naturalnego jak i ludzkiego, bo wszelka władza pochodzi od Boga i ten kto opiera się władzy opiera się Bogu. Współbrat zakonny Antoniego Węgrzynowicza ${ }^{4}$ Józef Męciński stał na stanowisku, że grzech to przeciwstawienie się woli Bożej i podążanie za własnymi upodobaniami i pragnieniami. Kaznodzieje tego okresu w swych homiliach „formułowali jednoznaczne sądy negatywne wobec grzechu i propagowali jako pozytywne cnoty chrześcijańskie, teologiczne oraz kardynalne" ${ }^{\text {. }}$.

Problem grzechu zdawał się być problemem obejmującym całego człowieka $\mathrm{i}$ to już od urodzenie, to grzech pierworodny ${ }^{6}$ bowiem

\footnotetext{
${ }^{1}$ Wprowadzenie do wystawy „Grzech. Obrazy grzechu $w$ sztuce europejskiej od XV do początku XX wieku”, kultura online.pl [dostęp 29 XII 2018].

${ }^{2} 12$ tom Sumy Teologicznej.

${ }^{3}$ J. G o 1 iń s ki, Peccata capitalia. Pisarze staropolscy o naturze ludzkiej i grzechu, Bydgoszcz 2002, s. 2-12.

4 Antoni Węgrzynowicz urodził się w 1658 roku, w Krakowie, w rodzinie mieszczańskiej Andrzeja i Katarzyny. Kształcił się w rodzinnym mieście u ojców dominikanów ${ }^{4}$. W dniu 3 lipca 1675 roku wstąpił do zakonu reformatów Prowincji Małopolskiej. Święcenia kapłańskie przyjął w 1682 r. W latach 1713-1714 był lektorem we Lwowie, a następnie 1714-1716 gwardianem klasztoru w tym mieście. W roku zaś 1716 objął funkcję gwardiana w konwencie krakowskim; pełnił ją tylko rok, gdyż został dotknięty chorobą. Zmarł 1721 r. w Krakowie.

5 B. R ok, Kilka uwag o dominikańskich kazaniach XVIII w., „Roczniki Humanistyczne" t. LXI z. 2 2013, s. 211-212.

${ }^{6}$ I. M r o c z k o w s k i, Zło i grzech. Studium filozoficzno- teologiczne, Lublin 2002, s. 302.
} 
pozbawiał go znamion rajskiej doskonałości i skazywał na borykanie się z pokusami i ograniczonością ,skażonej” natury.

Grzech pierworodny otwierał niejako drogę innym grzechom, które kategoryzowane są jako lekkie lub ciężkie. Grzechem powszednim (lekkim) jest niewielka obraza Bożego majestatu. Jego skutkiem jest oziębłość na łaskę i miłość Bożą, powoduję też łatwiejsze popadanie w inne grzechy ${ }^{7}$.

\section{Grzechy główne}

Najwięcej uwagi poświęcano w podręcznikach teologii moralnej zagadnieniu grzechów głównych. Uznawano je za wady główne, bo były zasadniczym źródłem wykroczeń i stawały się przyczyną innych wad moralnych ${ }^{8}$.

Stanowiły korzeń innych grzechów, nie było jednak zgodności wśród teologów czy wszystkie one są śmiertelne. Niektórzy uważali, że tak, inni twierdzili, że nie wszystkie niosą natychmiastowe potępienie.

Kanon tych grzechów otwierała pycha (superbia) dalej kaznodzieje i moraliści opisywali naturę chciwości (avaritia), nieczystość (luxuria), gniewu (ira), łakomstwa (gula), zazdrości (invidia), lenistwa(acedia). Ich przeciwieństwami, które miały wzmacniać duszę grzesznika w walce z pokusami były odpowiednio: pokora, szczodrość, czystość, umiarkowanie, cierpliwość i szczera pobożność ${ }^{9}$.

Pycha to pierwszy z grzechów głównych. Według definicji słownikowej: „to cecha kogoś, kto ceni siebie zbyt wysoko”. ${ }^{10}$ Wyrazów bliskoznacznych jest wiele: zadufanie, arogancja, zuchwałość, hardość, buta, ale i wiara w siebie, poczucie własnej wartości i godnośćc ${ }^{11}$. Pycha pojawia się w tradycji judeochrześcijańskiej. i ma coś wspólnego z klasyczną hybris (gr.) i żydowską hucpą. W światopoglądzie teo-

${ }^{7}$ A. De rd zi u k, Grzech $w$ XVIII wieku. Nurty w polskiej teologii moralnej, Lublin 1996, s. 110.

8 A. Szafulski, Życie cnotliwe podstawa moralności społecznej $w$ kazaniach A. Wegrzynowicza OFM Ref., „W nurcie Franciszkańskim” 12(2003), s. 145.

${ }^{9}$ A. De rdzi u k, Grzech w XVIII wieku. Nurty w polskiej teologii moralnej, Lublin 1996, s. 155.

${ }^{10}$ Wielki słownik języka polskiego, red P. Żmigrodzki https://wsjp.pl/index.php?id_ hasla=4423\&ind=0\&w_szukaj=pycha [dostęp 23 XI 2019].

${ }^{11}$ Słownik wyrazów bliskoznacznych, https://synonim.net/s\%C5\%82ownik-wyraz\%C 3\%B3w-bliskoznacznych( dostęp 23 XI 2019). 
centrycznym pycha alienuje jednostkę od Boga i społeczności. Ewagriusz z Pontu sytuuje próżność i pychę odpowiednio na szóstej i siódmej pozycji wśród ośmiu demonów. Dopiero później superbia i vana gloria (albo inanis gloria) (łac.) zostały połączone w jeden grzech grzech pychy. Św. Jan Kasjan przyznawał pysze główne miejsce - ostatnie w łańcuchu wad o wzrastającym ciężarze gatunkowym (pierwszym było obżarstwo). Dla Kasjana jest to najgorszy grzech, „bo kusi doskonałych”. Grzegorz Wielki stawiał pychę, „królową i matkę wszystkich wad", ponad pozostałymi grzechami głównymi, jako kategorię podstawową. Uważał, że zawładnięte nią serce poddaje się wszystkim innym wadom. Dodajmy, że również w porządku zaproponowanym przez Grzegorza i zmodyfikowanym przez bł. Henryka z Ostii pycha znajduje się na pierwszym miejscu, ale tuż po niej uplasowała się chciwość. Porządek ten stał się zresztą obowiązujący. Św. Grzegorz wyróżniał cztery warianty pychy. I tak: niektórzy ludzie wyłącznie siebie mają za przyczynę własnych talentów i osiągnięć. Inni przyznają wprawdzie, że owe dary zawdzięczają Bogu, lecz uważają, że im się one należą. Ludzie trzeciego typu szczycą się tym, czego nie posiadają. Czwartego, wreszcie, pysznią się swoją wyjątkowością, pogardzają tymi, którzy pozbawieni są cech, które sami posiadają. Analizując tyranię pychy, św. Grzegorz zaobserwował, że człowiek pyszny ma zaburzone poczucie sprawiedliwości i miłości bliźniego. Zajmuje się głównie podziwem dla siebie; z biegiem czasu drażnią go dobre strony bliźnich, zaczyna ich lekceważyć i nimi pogardzać ${ }^{12}$.

Obok wybitnych pisarzy Kościoła, pychę próbowali charakteryzować również kaznodzieja, a wśród nich Antoni Węgrzynowicz. Mówił on tak „Gdy próżna chwała opanuje wejście do serca ludzkiego nie uspokoi się póki siedem grzechów z sobą nie wprowadzi"13. Zachowanie pysznych może przybierać różne formy i objawiać się a różne sposoby: „najbardziej ze szlachetnego urodzenia pysznią się(... $)^{14}$. Są i tacy, którzy ,gdy ich szczęście (...) do wysokiego stanu wyniesie zmyślają sobie szlachectwo (...) rodziców, ojczyzny swojej wstydzą się z czasem za-

12 J. P e r t y-M r o c z k o w s k a, Siedem grzechów głównych dzisiaj, http://www.mat eusz.pl/mt/znak/sggd.htm [dostęp 29 XII 2018].

${ }^{13}$ A. W ę g r z y n o w i c z, Kazań niedzielnych księga pierwsza, to jest Siedem Trab zobjawienia Jana Świętego przeciw siedmiom głównym grzechom, Kraków 1708, s. 24.

${ }^{14}$ Tamże, s. 48. 
pierają się $(\ldots)^{15}$. Takie postępowanie $\mathrm{z}$ czasem prowadzi do obojętności, nie dbanie o potrzeby starszych i niedołężnych rodziców nie jest tylko grzechem przeciw IV przykazaniu staje się także czynieniem rozluźniającym i niszczącym, w pierwszej kolejności więzy rodzinne, po wtóre również cierpi na tym zbiorowość, która ponosić może konsekwencje tego typu zachowań. Jeśli człowiek, jak pokazuje Węgrzynowicz, z taką łatwością wyrzeka się rodziców, nie będzie reagował na potrzeby innych szukających wsparcia. Nie ma tu więc mowy o solidarności międzyludzkiej, czy budowaniu trwałych więzi. Opisy tych sytuacji świadczą bezspornie o tym, że były one obecne w życiu społecznym XVIII-wiecznej Rzeczpospolitej i pokazują z jakiej jakości życiem moralne było udziałem Polaków tej doby. Człowiek ulegający pysze, stawał się ostatecznie jednostką odizolowaną wyobcowaną, bo zorientowaną tylko na siebie.

Kolejnym grzechem w katalogu głównych była chciwość. Moraliści XVIII wieku twierdzili, że istnieje wiele pochodnych tego grzechu. Była to zatwardziałość serca na potrzeby ubogich, zbytni niepokój umysłu, gwałtowności pobudzająca do skrzywdzenia bliźniego przez zabranie lub nieoddanie jakiejś rzeczy, podstęp w słowach lub czynach. Św. Anzelm określa ją na przykład jako „wstrętną chorobę duszy”, św. Tomasz z Akwinu, mówi o chciwości w szerszym znaczeniu. Szerzej pojęta chciwość: „Jest nieumiarkowanym pożądaniem posiadania jakiejkolwiek rzeczy, natomiast w ściślejszym sensie jest to nieumiarkowane umiłowanie posiadania dóbr, jak też i pieniędzy"16. Wynika z tej definicji, że chciwość jest „miłością czegoś”, czyli posiada charakter emocjonalny. To nieumiarkowane umiłowanie dóbr doczesnych, zdobywanie ich i gromadzenie wiąże się z przywiązaniem do nich, niemal z bałwochwalczą miłością. Żądza bogacenia się, pokusa chciwości jest jedną z niedobrych skłonności człowieka. Nauka katolicka nie głosi wcale zasady pauperyzmu - czyli zubożenia ludności. Potępia tylko niemoralne metody bogacenia się i niewłaściwy sposób używania posiadanych bogactw. Św. Tomasz zauważa, iż chciwość w zdobywaniu i użytkowaniu dóbr obraża cnotę sprawiedliwości, gdyż narusza granicę

\footnotetext{
15 Tamże, s. 48.

16 J. U r y g a, Czym jest chciwość?, http://www.katolik.pl/czym-jest-chciwosc-,1295, 416,cz.html, (dostęp 29 XII 2018).
} 
tego, co jest należne bliźniemu ${ }^{17}$. Węgrzynowicz zaś wyjaśnia chciwość między innymi mówiąc: „Nie maja żadnej litości (...) nad chłopem zrujnowanym przez nieprzyjaciela, wiedzą, że nie ma o czym żyć, a przecież pańszczyzny, czynszu, gwałtem się upominają (...) ostatki zabierają wymyślnymi sposobami (...) nowe ciężary na nie kładą (...) na ostatek traktują nie jak Katoliki nie jak ludzie lecz gorzej niż bydlęta (...) a to wszystko pochodzi z chciwości do gromadzenia"18.

Kolejną grupą chciwców o której wspomina reformata, są kupcy. „Św. Ambroży twierdzi, że morze wzburzyło się nie mogąc ścierpieć łakomego, niesprawiedliwego kupca, to jest Judasza, który się w owej łódce między dwunastu Apostołami naddawał (...) ponieważ tedy przeciwko łakomym kupcom dziś się burzy nie tylko morze, ale i doktorowie święci obrócą tedy trąbę apokaliptyczną przeciw łakomym niesprawiedliwym handlom" "I9 . Zastanawiając się nad niegodziwym zachowaniem kupców, zwraca też uwagę na proceder często przez nich uprawiany, a mianowicie przetrzymywanie zboża: „Był bogacz, który podczas drogości wielkiej jeszcze na droższy czas zboże zatrzymywał gdy potem niespodziewanie staniało, z melancholii wielkiej nic nie mówił tylko te słowa: «Niestety mnie po pól czwarte pieniądza zboże»», ${ }^{20}$.

Zatem przestrzega by ci, którzy chcą się szybko wzbogacić na krzywdzie innych mieli świadomość, że mogą w konsekwencji zamiast zarobić stracić i ściągnąć na siebie gniew boży. Takie zachowanie w jego głębokim przekonaniu jest objawem braku uczciwość, solidarności międzyludzkiej, jest niegodne chrześcijanina.

Niezwykle ważnym z punktu widzenia właściwego funkcjonowania zbiorowości zdaje się być problem lichwy, nieodłącznie związany z chciwością. „Prawo naturalne zakazuje brać więcej niż dałeś”21. Czytamy ponadto u reformata, że lichwy zakazuje prawo kościelne, a także świeckie. Podkreśla, że lichwa pochodzi prosto z piekła. Ktoś, kto był lichwiarzem łamał prawo boże i nie zasługiwał na rozgrzeszenie, a w porządku ludzkim stawał się jednostką bardzo źle postrzega-

\footnotetext{
17 J. U r y g a, Czym jest chciwość?, http://www.katolik.pl/czym-jest-chciwosc-,1295, 416,cz.html, (dostęp 29 XII 2018).

18 A. W ę g r z y n o w i c z, Kazań niedzielnych księga pierwsza, to jest Siedem Trą z objawienia Jana Świętego przeciw siedmiom głównym grzechom, Kraków 1708, s. 71-72.

${ }^{19}$ Ibidem, s. 67.

${ }^{20}$ Ibidem, s. 94.

${ }^{21}$ Ibidem, s. 100.
} 
ną. Jak można było ufać człowiekowi, który ludzką niedolę wykorzystywał do tego by się wzbogacić.

Następnym problemem, o jakim wspomina franciszkanin jest kwestia osób, które gwałcą prawo robotnika do uczciwej zapłaty i nie wywiązują się z umowy: „trzeba robotnikowi całodzienną robotą znendznionemu nastać, naczekać, trzeba rzemieślnikowi kilka razy po nagrodę chodzić, trzeba raz, drugi, i (...) kupcowi(...) czekać"22.

Węgrzynowicz nie był jedynym kaznodzieją, który zagadnieniu temu poświęcał uwagę na ambonie, mówili o tym również jezuici ${ }^{23}$. Wspomina też o powtarzającej się często sytuacji, kiedy to umierający pozostawiają swym najbliższym w spadku własne długi. „Masz spłacić dług, bo jest na to prawo pod grzechem śmiertelnym obligujące. Im kto dłużej dług zatrzymuje tym ciężej grzeszy ${ }^{24}$.

Kolejna ludzka niedoskonałość to grzech nieczystości. Osiemnastowieczni teologowie wyjaśniali, że nieczystość to nieuporządkowane pożądanie lub używanie rozkoszy zmysłowych. Może, jak poucza reformat, mieszkać w słowach, myślach i uczynkach ${ }^{25}$.

Kaznodzieja podaje wiele przykładów grzechów nieczystości, ich konsekwencje mają wydźwięk nie tylko jednostkowy, ale w myśl nauki reformata skutki ich uderzają w całą społeczność, która skazana jest na życie w „symbiozie” z rozpustnikami. Skutki nieczystości są mnogie i różnorodne, dotyczą teraźniejszości a także egzystencji po śmierci: „Karze (...) osoby na zdrowiu chorobami nieuleczonymi, szkodami, niebłogosławieństwem w rzeczach doczesnych w gospodarstwie, handlach, karze niesławą i pogardą miedzy ludźmi, a osobliwie młodzieńskie lata skalane cielesnością Pan Bóg karze złymi i nie do najpospolitsza takowego ludziom w małżeństwie dzieci nie daje o czym Duch Święty przestrzega każdego młodzieńca(...) Zgoła Pan Bóg i sama natura karze nieczystych niepłodnością w stanie małżeńskim" "26.

Wydawać by się mogło, że te przypadłości dotykające najbardziej intymnej sfery człowieczej egzystencji, dotyczą tylko dwóch grzeszących podmiotów. Tak jednak nie jest, bo należy pamiętać, że krzywda

${ }^{22}$ Ibidem, s. 108

23 A. S molińs k a, Społeczeństwo polskie $w$ kazaniach jezuickich przełomu XVII i XVIII wieku. Kielce 2005, s. 107-124.

${ }^{24}$ A. W ę grzy n ow i c z, s. 109.

${ }^{25}$ Ibidem, s. 129.

${ }^{26}$ Ibidem, s. 135. 
wyrządzona drugiemu człowiekowi w jakimkolwiek aspekcie jego życia może stać się źródłem cierpienia nie tylko tej zranionej jednostki, lecz uderza w jej najbliższych, konsekwencji w całą zbiorowość.

Dalej opisując grzechy główne, Węgrzynowicz poświęca uwagę gniewowi. Szkodzić bliźniemu jest łatwo, przysięgać fałszywie oczerniać przeklinać przychodzi człowiekowi bez większego trudu, szczególnie gdy kierując się nienawiścią, robi to dla zemsty: „Jeżeli gdyś takie przekleństwa mówił, tak cię pasyja twoja przemogła, że też i wola twoją skłoniłeś do tego, iż radbym był nieszczęściu onemu bliźniemu, choć tego prędko żałował, postaremu jużeś śmiertelnie zgrzeszył"27.

Zdaje się zatem, że gniew bardzo mocno wpływa na jakość życia społecznego. Im więcej gniewu tym, mniej solidarności i współczucia. „Robi miejsce” wielu zachowaniom, które nie powinny pojawiać się W życiu chrześcijan. Węgrzynowicz analizując różne aspekty gniewu zwraca uwagę np. na małżonków, którzy nie okazują sobie szacunku, gniewają się na siebie. Franciszkanin podaje, że to grzech śmiertelny. Niezgoda małżeńska owocująca w określony skutki staje się zgorszeniem dla dzieci, służby i wszystkich patrzących na to, co się dzieje w domu pozbawianym poszanowania wzajemnego i miłości.

Kolejnym grzechem, o którym poucza reformata jest obżarstwo i pijaństwo. Tłumaczy dalej, że pijaństwo jest grzechem śmiertelnym, jeśli następowało dobrowolne pozbawienie się używania rozumu. Było napiętnowane, bo występowało dość często i stanowiło bez wątpienia zagrożenie dla moralności i ładu życia społecznego, szczególnie w jego rodzinnym wymiarze ${ }^{28}$. Przestrzega wiernych, którzy folgują żądzy nieumiarkowanego przyjmowania pokarmów i napojów, szczególnie tych, pod wpływem, których ludzki rozum nie funkcjonuje sprawnie. Człowiek upojony alkoholem jest jednostką aspołeczną, która zamiast wzbogacać życie zbiorowości, powoduje jego ubożenie i degradację. Szczególnie przykrym w przekonaniu reformata jest grzech pijaństwa, w który popadają osoby, mające dawać przykład i być dla swych poddanych wzorem do naśladowania. „Trzeba wiedzieć, że grzech pijaństwa to jest w ludziach zwierzchności jako

\footnotetext{
${ }^{27}$ Ibidem, s. 325 .

${ }^{28}$ Ibidem, s. 166. B, R o k, Problem walki z choroba alkoholowa w polskim piśmiennictwie religijnym XVIII w. [w:] Medycyna nowożytna. Studia nad kulturą medyczną, t. 6 (1999) z. 2, s. 63-76.
} 
mający nad innemi staranie daleko cięższym grzechem jest niźli w człowieku, jakim pospolitym (...). Nad to częstokroć u takich ludzi pijaństwo wiele inszych grzechów ciężkich za sobą pociąga: jako jest pogorszenie dane poddanym, czeladzi dziatkom albo parafianom swoim, jeżeli kto jest Duchownym: przeto na spowiedzi nie dość jest takiemu powiedzieć, iż to było z pogorszeniem poddanych, domowych dziatek swoich",29.

Napiętnuje również pijaństwo kobiet: „za cięższy grzech poczytują pijaństwo białogłowie niźli w mężczyźnie. Pijaństwo w niewieście strasznym świętokradztwem jest"30.

Zazdrość, która jest kolejnym przywoływanym przez kaznodzieję grzechem, podobnie jak chciwość i gniew mocno odciska się na życiu zbiorowości. Zazdrość (zelus, livor) jest to uczucie niechęci do innej osoby powodowane prawdziwym (albo tylko rzekomym, ale w dobrej intencji) zagrożeniem z jej strony dóbr osobistych, zwłaszcza emocjonalno-społecznych. Stąd o Bogu można powiedzieć, że jest „,zazdrosny” broniąc swego prawa do wyłącznej czci, ale nigdy nie można użyć o Nim wyrażenia, iż jest ,zawistny” (por. Wj 20, 5; Pwt 4, 25; Joz 24, 19) ${ }^{31}$.

Zazdrość stanowi wadę główną, a więc zakorzenioną w człowieku skłonność do czynienia zła, która „może prowadzić do najgorszych występków". To przeciw niej skierowane jest dziesiąte przykazanie dekalogu. Zazdrość może być również traktowana jako konkretny czyn i wtedy sama jest grzechem oraz społecznym nieporządkiem. Staje się wręcz grzechem śmiertelnym, gdy człowiek dobrowolnie „,̇yczy bliźniemu poważnego zła"32.

Zazdrości niszczy relacje międzyludzkie i nie pozwala na tworzenie nowych. Ten, kto zazdrości nie może zastać niczyim przyjacielem. Nie może nikomu pomóc, bo obawia się by ten, komu okaże współczucie nie miał więcej niż on.

Ostatnim z grzechów omawianych przez krakowskiego teologa jest lenistwo. Lenistwo jest piętnowane zarówno przez Stary, jak i Nowy Testament. Jeśli idzie o ten pierwszy, to szczególnie tzw. księgi mądrościowe nie wyrażają się o nim pochlebnie. Wystarczy wziąć do

\footnotetext{
${ }^{29}$ A. W ę gr z y now i c z, s. 273.

${ }^{30}$ Ibidem, s. 283

31 J. S z a r y n, Zawiść, http://www.szyran.republika.pl/zazdrosc.pdf, (dostęp 30 VI 2018).

${ }^{32}$ S. K r a w c z y k, Zazdrość w Katechizmie i Biblii Tysiąclecia, http://przedmurze.pl/ zazdrosc-w-katechizmie-i-zazdrosc-w-biblii-1233 [dostęp 1 VII 2018].
} 
ręki choćby Księgę Przysłów czy Księgę Mądrości Syracha, by przekonać się, że lenistwo jest ciężkim grzechem przeciwko Bogu, samemu sobie i bliźniemu. Nowy Testament też ukazuje tę postawę w negatywnym świetle (por. np.: Tt 1, 12 czy 2 Tes 3, 10nn).

$\mathrm{W}$ początkach monastycyzmu IV i $\mathrm{V}$ wieku acedia - jako grzech główny - była rozumiana przez zmęczenie, znużenie i brak należytej uwagi na modlitwie. Zagrażał im bowiem - jak to ujmuje Psalm 91 - mór, który niszczy w południe. Demon acedii upodobał sobie, jako najlepszy czas do ataku, samo południe, czyli szóstą godzinę dnia. Uwagę na acedię w pracy duchowej nad sobą zwrócił Ewagriusz z Pontu. Wymienił ją jako jednego $\mathrm{z}$ ośmiu demonów (na szóstym miejscu) zagrażających życiu monastycznemu. Lenistwo było traktowane jako baza dla rozwoju acedii. Demon ten podsuwa człowiekowi wszystkie możliwe pokusy i złe myśli, bierze duszę w posiadanie, obezwładnia rozum i wolę. Ogarnięty nim nie jest w stanie osiągnąć wyciszenia wewnętrznego (gr. hesychia), staje się porywczy w mowie, nieskory do okazywania komukolwiek szacunku, łatwo wyrządza innym krzywdę. Tę naukę o szeregu demonów przejął św. Jan Kasjan, inny ojciec pustyni, autor dzieła pt. $O$ ośmiu złych myślach.

Wszystkie grzechy główne pojmował jako łańcuch, w którym każde ogniwo łączy się z następnym. Demon acedii szczególnie upodobał sobie mnichów, którzy nie są czujni i dobrze przygotowani do zmagań duchowych. Atakując ich złymi myślami, czyni ich krnąbrnymi i leniwymi włóczęgami, wałęsającymi się niepotrzebnie od monasteru do monasteru oraz myślącymi jedynie o zaspokojeniu podstawowych potrzeb życiowych, czyli o jedzeniu i piciu. Św. Jan Chryzostom zauważył, że acedia dotyka również ludzi świeckich, a jej skutkiem są np. samobójstwa. Św. Izydor z Sewilli wiązał acedię z ospałością i niedyskrecją umysłu, rozbieganiem, gadulstwem i pustą ciekawością. Teolog i pedagog angielski, Alkuin, do tych opisów acedii dodał postawę letniości, wędrówkę z miejsca do miejsca, szemranie i zrzędliwość. Jednocześnie ojcowie Kościoła przestrzegali przed lenistwem, jak np. św. Bazyli Wielki, który uczył: „Jakikolwiek pretekst do lenistwa jest pretekstem grzesznym"33.

33 A Zi eliński, Wychowanie do wolności od lenistwa, www.pedkat.pl/images/ czasopisma/pk2/art08 [dostęp 30 VI 2018]. 
Katechizm Kościoła katolickiego zaś umieszcza lenistwo pośród takich przywar, jak: obojętność, niewdzięczność, oziębłość i znużenie. Każda $\mathrm{z}$ tych cech jest grzechem przeciwko Bożej miłości. „Obojętność zaniedbuje lub odrzuca miłość Bożą; nie uznaje jej inicjatywy i neguje jej moc. Niewdzięczność pomija lub odrzuca uznanie miłości Bożej, jak również odwzajemnienie się miłością na miłość. Oziębłość jest zwlekaniem lub niedbałością w odwzajemnieniu się za miłość Bożą; może zakładać odmowę poddania się poruszeniu miłości. Znużenie lub lenistwo duchowe posuwa się do odrzucenia radości pochodzącej od Boga i do odrazy wobec dobra Bożego..." (KKK 2094) ${ }^{34}$.

Moraliści XVIII-wieczni definiując lenistwo sięgali do św. Tomasza i mówili, że jest ono „pustką w duszy”, ,głębokim znudzeniem” wobec dóbr duchowych ze względu na wysiłek fizyczny, jakiego wymagają. Węgrzynowicz podkreśla, że człowiek „rodzi się na pracę” i każdy rodzaj lenistwa ten skierowany ku życiu duchowemu czy ku pracy jest obrażą majestatu Bożego i przeciwstawieniem się Bożemu zamysłowi.

Przy pomocy tych barokowych exempli, Węgrzynowicz chce powiedzieć słuchaczowi i czytelnikowi, że każdy czyn dobry i zły znajdzie odzwierciedlenie w wymiarze życia wiecznego, przyniesie zbawienie lub potępienie. Wydaje się być również faktem oczywistym, że wyżej wspominane przez kaznodzieję grzechy, podkopują fundament ładu społecznego i zaufania między ludźmi. Krzywda i niesprawiedliwość, poza wymiarem eschatologicznym, daje skutki także $\mathrm{w}$ teraźniejszości jest to brak solidarności z drugim człowiekiem, zanik więzi społecznej ${ }^{35}$.

\section{Zakończenie}

Celem artykułu było uzmysłowienie, że grzech jest czynnikiem wpływającym negatywnie nie tylko na relacje człowiek - Bóg, ale również na związki międzyludzkie. W nauczaniu społecznym XVIII-wiecznego reformackiego kaznodziei widzimy wyraźnie istnienie tej płaszczyzny

\footnotetext{
34 J. Molk a, Lenistwo, http://www.niedziela.pl/artykul/81660/nd/Lenistwo [dostęp 30 VI 2018].

35 S. Z y d e k, Strach i poczucie bezpieczeństwa jako elementy budujace polska mentalność w XVIII wieku w świetle kaznodziejstwa Antoniego Wegrzynowicza (1658-1721), Toruń 2018, s. 19-33.
} 
rozumienia grzechu jako „niszczyciela” ładu społecznego i moralnego. Węgrzynowicz analizując grzech np. pijaństwa czy nieczystości nie mówi tylko i wyłącznie o jego konsekwencjach w życiu pojedynczych jednostek, ale podkreśla zawsze, iż grzechy te dotykają wielu osób, które choć nie grzeszą to odczuwają boleśnie skutki grzechu w wyniku degradacji relacji między ludźmi.

\section{Bibliografia}

Derdziuk A., Grzech w XVIII wieku. Nurty w polskiej teologii moralnej, Lublin 1996.

Goliński J., Peccata capitalia. Pisarze staropolscy o naturze ludzkiej i grzechu, Bydgoszcz 2002.

Krawczyk S., Zazdrość w Katechizmie i Biblii Tysiąclecia, http://przedmurze.pl/ zazdrosc-w-katechizmie-i-zazdrosc-w-biblii-1233

Mroczkowski I., Zto i grzech. Studium filozoficzno- teologiczne, Lublin 2002.

Molka J., Lenistwo, http://www.niedziela.pl/artykul/81660/nd/Lenistwo

Perty J. Mroczkowska, Siedem grzechów głównych dzisiaj, http://www.mateusz.pl/ $\mathrm{mt} /$ znak/sggd.htm.

Rok B., Problem walki z choroba alkoholowa $w$ polskim piśmiennictwie religijnym XVIII w. [w:] Medycyna nowożytna. Studia nad kulturą medyczną, t. 6 (1999) z. 2 s. 63-76.

Rok B., Kilka uwag o dominikańskich kazaniach XVIII w., „Roczniki Humanistyczne" t. LXI z. 22013.

Smolińska A., Społeczeństwo polskie w kazaniach jezuickich przełomu XVII $i$ XVIII wieku. Kielce 2005 s. 107-124.

Szafulski A., Życie cnotliwe podstawa moralności społecznej w kazaniach A Wegrzynowicza OFM Ref., „W nurcie Franciszkańskim” 12(2003).

Szaryn J., Zawiść, http://www.szyran.republika.pl/zazdrosc.pdf,.

Uryga J., Czym jest chciwość?, http://www.katolik.pl/czym-jest-chciwosc-, 1295,416,cz.html

Węgrzynowicz A., Kazań niedzielnych księga pierwsza, to jest Siedem Trąb z objawienia Jana Świętego przeciw siedmiom głównym grzechom, Kraków 1708.

Zieliński A., Wychowanie do wolności od lenistwa, www.pedkat.pl/images/ czasopisma/pk2/art08.

Zydek S., Strach i poczucie bezpieczeństwa jako elementy budujace polska mentalność w XVIII wieku w świetle kaznodziejstwa Antoniego Wegrzynowicza (1658-1721), Toruń 2018. 
SYLWIA ZYDEK

\title{
GRZECH JAKO CZYNNIK DEZINTEGRUJĄCY ŻYCIE SPOŁECZNE TEMATEM KAZNODZIEJSKICH ROZWAŻAŃ ANTONIEGO WĘGRZYNOWICZA (1658-1721)
}

Streszczenie: Artykuł jest próbą analizy niewielkiego wycinak twórczości kaznodziejskiej znanego w kręgach franciszkańskich w XVIII kaznodziei Antoniego Węgrzynowicza. Nauka o grzechu w okresie baroku zajmowała znaczące miejsce w rozważaniach teologów moralistów, czy dogmatyków. Grzech mógł być analizowany z perspektywy jego skutków w życiu obecnym, echo tych myśli słyszalne jest wyraźnie w kazaniach franciszkanina, ale mógł być również ujmowany jako czynnik, niszczący ludzkie życie po śmierci, jako przyczyna potępienia. I tak pojmowany grzech niósł strach i lęk, bo człowiek, który grzeszył miał świadomość, że czyniąc źle niszczy swoje życiu ,tu” i ,tam”.

Słowa klucze: cnota, dobro, zło, grzechy główne, ład społeczny, potępienie.

\section{SIN AS A DISINTEGRATING FACTOR OF SOCIAL LIFE IN THE SERMONS OF ANTONI WEGGRZYNOWICZ (1658-1721)}

\begin{abstract}
The article is an attempt at analysing a small fragment of preaching of Antoni Węgrzynowicz, known in Franciscan circles in the $18^{\text {th }}$ century. In the Baroque period, teaching about sin occupied a significant place in the thought of moral theologians and dogmatists. Sin could be analysed from the perspective of its effects in current life (the echo of these thoughts can clearly be heard in the Franciscan's sermons), but it could also be presented as a factor destroying human life after death and a cause of damnation. Such an understanding of sin was a bearer of fear, as the sinner was aware that by wrongdoing he destroyed his life "here" and "there".
\end{abstract}

Keywords: virtue, cardinal sins, social order, damnation.

Translated by Hanna Rybkowska 
126

SYLWIA ZYDEK 